\title{
Points of Indo-Arab Intertwined Connections in Indian Literary Texts
}

\author{
Khalid Sultan Thabet Abdu \\ Faculty of Science and Humanities \\ Sattam bin Abdul Aziz University \\ P.O. Box: 710, Index: 11912 \\ Al-Aflaj, Layla \\ Kingdom of Saudi Arabia
}

\begin{abstract}
Amitav Ghosh is one of the contemporary writers, who write about Indo-Arab relations in his literary texts. He links the past with the present events, as he has been influenced by the study of history in his M.A. Degree. He tries to show the effect of the past on the current situation of the present time. In his novel, In an Antique Land, Ghosh associates India with Arabia through maritime trade, superstition and supernatural element. The novel is also a story of two Indian travellers to Egypt: an Indian slave's journey in ancient times and Ghosh's trip in the modern times. In his second novel, The circle of Reason, Ghosh connects India with Arabia historically via silk road and then currently through oil industry that plays a vital role to attract the attention of Indians to go to Arabia. In The Hungry Tide, Ghosh bonds the two civilisations through the mythical figures of the two twins of Bon Bibi and her brother Shah Jongoli.
\end{abstract}

Keywords: Maritime, ancient, modern, Bon Bibi, Shah Jongoli, Islam, Hinduism.

\section{Introduction}

Amitav Ghosh has carved a niche in the contemporary Indian writing in English. He is influenced by the academic study of history, as he acquired his B. A. in History from St. Stephen's College in Delhi in 1976. His novels reflect historicity as history is always present in his fictional and non-fictional works. This study deals with the concept of history and the manner in which Ghosh retraces the interconnections between Indian and Arab cultures starting from the very ancient times till the contemporary period. Therefore, one of the significant characteristics in Ghosh's fiction is that he makes two narratives- one is about the past and the other one is about the present. In his writing, he shows the impact of the past on the current events in contemporary times. He portrays his characters as wandering personals moving between Arabia and India throughout history without the impact of Westerners. Unlike the other writers, who depict the presence of the West in their literary works, Ghosh makes the departures and arrivals of his characters not merely to the West, rather to the peripheries of India, Yemen, Egypt and Tunisia. He retraces histories and routes of travel in which he interrogates the role of West as paradigmatically normative. Besides, the focus is not only on privileged migrants, rather on very ordinary people roaming between the peripheries of Arabia and India. Hence, it is an encountering discourse to the paradigm of Eurocentric discourse of journey.

\section{General Analysis}

In the very beginning of his life, Amitav Ghosh comes across his grandfather's bookshop in which he gets a chance to read many novels that enable him to enrich his mind with the concept of globalization. In his article which is entitled, "The March of the novel through History", Ghosh writes: "I don't remember ever having come across a bookshelf like my uncle's: one that had been largely formed by this vision of literature, by a deliberate search for books from a wide array of other countries" (294). It is from the gate of literature that Ghosh navigates into the other hidden parts of the world. In this regard, he states: "But the truth is that fiction has been thoroughly international for more than a century" (295).

However, in his academic life, Ghosh paid a visit to Egypt in order to do a field work in Latfia, which is near Cairo, as a part of his anthropological study. In the mean time, he visited Tunisia in order to study Arabic language. During his sojourn in the Arab world, he wrote two novels (The Circle of Reason and In an Antique Land) as part of the influence of Arab culture on his narrative style. 
Ghosh shows the links that bond Indian culture with the Arab one as well as the relationship that connects the two civilizations throughout history. The most important thing here is that Ghosh goes back over these two cultures in his literary works because they are "antique civilizations".

Historically, Arabs came to India in a great number after the death of Prophet Mohammed. Islam gave the Arab tribes unity and zeal, so they launched on military expansion, which resulted in the occupation of the western coast of India. After the conquest of Sind in $712 \mathrm{AD}$, the Arabs penetrated into the hinterland of India and in the second half of the eighth century they continued to make their attacks on western coast of India. The most successful raids were against the Saurastra port and town of Barada which resulted in their prosperous commerce in Western India. With the passage of time, the Arab military forces retreated in India and did not go beyond the Sind. They stopped at its north-western fringe, and then they shifted their purpose to trade activity to encompass many coastal cities in India, which are today part of Kerala, Goa and Manglore. By the tenth century, innumerable Arabs travelled to India, they settled in "the coastal areas of Cutch, Saurastra and Gujarat and were carrying on the profession of trade and commerce" (Jain 166).

The Arab influence on India lasted for centuries. Walter J. Fischal divided the existence of Arabs in India into two broad periods. The first one starts from the eighth century with the invasion of Mohammed Ibn Qasim in 712 AD and ends with the close of the fifteenth century. The second period commences with the establishment of the Moghul Empire by Babur and ends with the foundation of Pakistan today (139-40). During the medieval times, several voyagers came to India from the Arab countries. These travellers played a role in bringing about social and cultural changes in this country, especially during the Mughal era. Therefore, the decline of Byzantine Empire in the West and the rise of Arabs resulted in opening several trading centres to their merchants and travellers in the East and the Far East.

Obviously, the Indian Ocean provided routes to India through the Arabian Gulf and the Arabian Sea. But before the discovery of the Cape of Good Hope, Europeans used to go to India overland through Central Asia, or, they used the sea route via the Mediterranean. When reaching Egypt "a journey had to be performed by caravan from Alexandria to the Isthmus of the Suez in order to reach the Arabian Sea from Europe" (Kaul XXV). However, before reaching the Arabian Sea, they had to sail through the Red Sea and from there to the Gulf of Aden to get to their last destination; such a long-distance navigation to the East had been used for a long time before the opening of the Suez Canal.

Basically, In an Antique Land is a story of two Indian travellers to Egypt: an Indian slave's journey in ancient times and Ghosh's trip in the modern times. Conversely, it also portrays the voyage of Abraham Ben Yiju, an Arab Jewish traveller, who came originally from Tunis to India via Egypt and Aden in 1132 AD and settled in Mangalore for seventeen years. The first Indian traveller is Bomma who went to Egypt on several occasions as a representative of Ben Yiju to do business on behalf of his master in the twelfth century. He is known by historians as the slave of MS H.6-the index number in which he first appears. Whereas, the second traveller from India is Amitav Ghosh who goes to Egypt for the sake of tracing the footsteps of the Indian slave-an undertaking which takes ten years. In the meantime, Ghosh also visits Mangalore to investigate the etymology of the slave's name and to take notes on the village's cultural and religious practices. The scholarly journey of the writer results in unravelling the real identity of the slave and his religion.

In an Antique Land, Ghosh attempts to enhance the bond between India with Arabia via maritime trade in the medieval times. The novel shows that: "North Africans appear to have had a particular affinity for the flourishing trade between the Mediterranean and the Indian Ocean" (55). At that time, Mangalore became a cosmopolitan city, where Indians and Arabs practiced their trade activity peacefully without any hindering or obstacles. Characters are involved in intermarriage process, like that one relation that links Ben Yuji with the Indian girl in the novel. The sub-plot of the narrative talks about the journey of the fictional character 'Amitab' to Egypt and the encountering episodes between him and his Egyptian interlocutors. During his sojourn in Egypt, he comes across different episodes of similarities and differences of the two cultures. Amitab is introduces by his Egyptian host, Ustaz Sabry, as "a student from India . . . a guest who had come to Egypt to do research. It was their duty to welcome me into their midst and make me feel at home because of the long tradition of friendship between India and Egypt". One of the guests of Ustaz Sabry describes the brotherly hood that links Indians with Egyptians saying: "The people of Egypt and India have been like brothers for centuries" (168). 
Besides, Egypt and India are connected politically and the politicians of both countries supported each other: "Mahatma Ghandhi", for example, "had come to Egypt to consult Sa'ad Zaghloul Pasha, the leader of the Egyptian nationalist movement, and later Nehru and Nasser had forged a close alliance" (134).

Moreover, the novel also concentrates on the similarities between the Egyptian and the Indian cultures regarding the beliefs in superstition, which is connected with supernatural element. In Egypt, for example, people tell Amitab about the miracles of saint of Abu-Kanaka, so when he died: "he was universally mourned and the people of the village built him a special grave, right next to the canal. Later, he even came to be acknowledged as the guardian Saint of the village" (119). likewise, many people believe in the supernatural power of Sidi Abu-Hasira, as he "had crossed the Mediterranean on a rush mat, which was why he was called 'Sidi Abu-Hasira' 'The Saint of the Mat'" (329). Indians, too, have the same belief in saints. In an Antique Land illustrates the common belief in supernatural power among Indian people. In Mangalore, for example, when the constructers wanted to establish the road; and it was by incident that the shrine was on the way of the road. They were forced to deviate the road in such way as to avoid touching the shrine because, "there was a miracle: their bulldozers were immobilized soon after they had begun to move; they were frozen to the ground before they could touch the shrine's walls" (265).

However, that kind of interconnection and connectivity come to an end, especially when it comes to contact with religious matters of Islam and Hinduism. Therefore, there are many encounters between Amitab and his Egyptian interlocutors in this novel, which show encountering incidents. In an Antique Land probes deep into the conflicts between the two diverse cultures of Egypt and India, at the heart of which lies the dichotomy of Islam and Hinduism. While in Egypt, Ghosh has many encounters with local people. The cultural differences of both countries are portrayed obviously through varied episodes that take place between the anthropologist and his interlocutors. An important facet of Ghosh's life among the Arabs is the binary of Muslim/Hindu, which resurfaces in Egypt when the Arab Muslims come to know about Hindu traditions. Such Hindu traditions as burning the dead, worshipping idols or cows, lack of circumcision for both men and women are the moot points in Ghosh's encounter, which give rise to antagonistic reactions about his presence there. Wherever he goes to many places in Egypt, he has been asked by Egyptians about three Indian rituals of circumcision, worshipping cows and burning dead. It is only Nabil, who justifies the curiosity of his Egyptian people, saying: "They were only asking questions ... like you do; they didn't mean any harm. Why do you let this talk of cows and burning and circumcision worry you so much. These are just customs; it's natural that people should be curious. These are not things to be upset about" (204).

The same issues give vent to a verbal clash between the Indian scholar and the Arab Imam Ibrahim. In this scene, however, Imam Ibrahim attacks Hindu culture, calling the Hindus "savages" who burn their dead, an act which Ibrahim calls "a primitive and backward custom" (235). Ibrahim's attack on the Indians has no religious-Islamicgrounds. Rather, he compares the Indian nation with the Western; hence he proves a mentally colonised figure. For people like Ibrahim overtaken by Western civilisation, modernity is defined in terms of "the material circumstances of their lives in exactly the same way that a university economist would" take (200). Referring to Westerners, Ibrahim declares, "They're not an ignorant people. They're advanced, they're educated, they have science, they have guns and tanks and bombs" (235). In their shameful encounter, each one boasting of his country's technological proximity to the West, Ghosh acknowledges that both were delegates from two superseded civilizations, vying with each other to establish a prior claim to the technology of modern violence. ... We would have known, both of us, that all that was mere fluff: in the end, for millions and millions of people on the landmasses around us, the West meant only this-science and tanks and guns and bombs. (236)

The circle of Reason, explores also the historical link between India and Arabia. The narration of the novel flips flop between the past and the present. People of the two nations mingle with each other for centuries. In the past, they were connected through the trade's route as well as the silk route that joined the ancient world all together. Ghosh points out in The Circle of Reason that, "Indian cloth was found in the graves of the Pharaohs", and that, "The whole of the ancient world hummed with the cloth trade. The Silk Route from China, running through central Asia and Persia to the ports of Mediterranean and from there to the markets of Africa and Europe, bound continents together for more centuries than we can count" (56). The location of Arabia plays a lucrative role in trade's activity between the East and the West. The fictional city of al-Ghazira in the novel, according to Amitav Ghosh, was: "a merchant's paradise, right in the centre of the world, conceived and nourished by the flow of centuries of trade. Persians, Iraqis, Zanzibari Arabs, Omanis and Indians fattened upon it and grew rich" (221). However, in the present times, many people draw their attention to this part of the world, especially after the discovery of oil. 
Indians workers migrate to Arabia seeking for better incomes. Plenty of jobs are available for Indians in Arabia and it becomes a utopian place for many Indians due to the job opportunities there. Therefore, the number of Indian travellers increases to an extent as it extends the percentage of the original people, especially in Kuwait, U A E, Qatar and Bahrain. In Kuwait, for example, the percentage of the foreigners reaches seventy percent of the total population.

Amitav Ghosh in his essay, "Petrofiction: The Oil Encounter and the Novel”, equates the 'Spice Trade' of the ancient times and the 'Oil industry' of the late twentieth century from two angles. He finds out that both of them are responsible for bringing 'economic value' as well as generating 'military and cultural encounter'. He writes, "oil is clearly the only commodity that can serve as an analogy for pepper" (75). Juxtaposing the history of the two products, Ghosh pinpoints the doom they have brought to the exporting nations. The competition for the spice trade brought Portuguese forces to India in the ancient times; likewise, the oil attracted the American and British forces to come to the Arabian Peninsula. Therefore, both products function as catalyst for stimulating European colonisation to invade Eastern countries throughout history.

In his novel, The Hungary Tide, Ghosh depicts the mutual interactions between Arabs and Indians since ancient times. In this fictional work, Ghosh links the Arab civilization along with the Indian one through the mythical figures of the two twins of Bon Bibi and her brother Shah Jongoli. The legendary characters had come originally from the sacred city of Al-Madina in Arabia. When they grew up, they had been selected for "a divine mission", as they, "were to travel from Arabia to 'the country of eighteen tides' . . . in order to make it fit for human habitation" (103). In the medieval times, this region had been trodden by the famous Arab traveller, Ibn Battuta. Besides, this "tide country" also had been lived by diversity of multinational people and Arabs were included here.

Therefore, Amitav Ghosh is one of the contemporary writers who shed lights on Indo-Arab mutual connection throughout history. He shows the manner in which Easterners are mutually connected with each other without interfering of the Westerners. It is not only that; rather, Ghosh proves in his literary works that the Westerners held the responsibility for bringing violence to the Eastern countries in which violence and riots replace mutual interaction by implementing their ideology of divide and rule in order to monopolize the wealth of the colonized countries.

\section{Works Cited}

Fischel, Walter J. "Jews and Judaism at the Court of the Moghul Emperors in Medieval India." Proceeding of the American Academy for Jewish Research 18 (1948-1949): 137-77.

Ghosh, Amitav. The Circle of Reason .New Delhi: Ravi Dayal, 1986.

---. In an Antique Land. New Delhi: Ravi Dayal, 1992.

---. The Imam and the Indian: Prose Pieces. New Delhi: Permanent Black, 2002.

---. "Petrofiction: The Oil Encounter and the Novel." The Imam and the Indian. New Delhi: Ravi Dayal, 2002. 7589.

---. "The March of the Novel through History: the Testimony of my Grandfather's Bookcase" The Imam and the Indian: Prose Pieces. New Delhi: Ravi Dayal, 2002. 287-304.

---. The Hungry Tide. New Delhi: Harper Collins, 2004.

Jain, V. K. "The Role of the Arab Traders in the Western India during Early Medieval Period." History and Culture Series: Essays on Ancient India. Ed. Raj Kummar. New Delhi: Discovery, 2003. 164-71.

Kaul, H.K., ed. Introduction. Travellers' India: An Anthology. By Kaul. Delhi: Oxford UP, 1997.XX-XXXIV. 